\title{
Implementasi Work from Home terhadap Motivasi dan Kinerja Dosen di Indonesia
}

\author{
Pristiyono $^{1}$, Muhammad Ikhlash ${ }^{2}$, Mulya Rafika ${ }^{3}$, Dinda Karasinta Hasibuan ${ }^{4}$ \\ 1) Fakultas Ekonomi dan Bisnis Universitas Labuhanbatu \\ Email:paktio16@gmail.com \\ ${ }^{2)}$ Politeknik Negeri Batam \\ Email:ikhlash@polibatam.ac.id \\ 3) Fakultas Ekonomi dan Bisnis Universitas Labuhanbatu \\ Email : mulya_rafika@yahoo.co.id \\ 4) Fakultas Ekonomi dan Bisnis Universitas Labuhanbatu \\ Email: dindacantik7877@gmail.com
}

\begin{abstract}
Abstrak
Pandemi Covid-19 berdampak negatif pada berbagai aspek kehidupan termasuk bidang pendidikan tinggi. Dalam upaya memutus rantai Covid-19 pemerintah mengeluarkan kebijakan bahwa pelaksanaan kegiatan PT tridharma dilakukan secara online / online dengan konsep work from home (WFH). Kehadiran work from home (WFH) menimbulkan pro dan kontra di kalangan akademisi. Hasil pengujian antar variabel adalah sebagai berikut: 1) Kerja dari rumah (WFH) berpengaruh langsung dan signifikan terhadap motivasi. Dimana nilai CR sebesar 13,914> 1,96 dan nilai p $(0,000)$ lebih kecil dari 0,$05 ; 2)$ Bekerja dari rumah (WFH) berpengaruh langsung dan signifikan terhadap kinerja. Dimana nilai CR sebesar 2.557> 1.96 dan nilai p (0.011) lebih kecil dari 0.05; dan Motivasi tidak berpengaruh langsung dan signifikan terhadap kinerja. Dimana nilai CR 1,581 <1,96 dan nilai $\mathrm{p}$ $(0,114)$ lebih besar dari 0,05 . Hasil penelitian ini memberikan gambaran tentang konsep bekerja dari rumah dalam bidang pendidikan khususnya perguruan tinggi hanya dapat melaksanakan kegiatan pendidikan / pengajaran yang dilakukan secara online dengan aplikasi yang dapat digunakan bersama oleh dosen dan mahasiswa seperti Google kelas, e-learning dan lain-lain Kegiatan penelitian semacam itu juga dapat dilakukan di rumah dengan menggunakan formulir Google dalam menyebarkan kuisioner, namun kegiatan pengabdian masyarakat belum menemukan solusinya. Kegiatan kerja lainnya yang terkait dengan pelayanan akademik masih dilakukan dengan work from home (WFH) dan setiap kegiatan dipantau secara berkala.
\end{abstract}

Kata Kunci: work from home, motivasi, kinerja.

\begin{abstract}
The Covid-19 pandemic has had a negative effect on various aspects of life including the field of tertiary education. In an effort to break the Covid-19 chain the government issued a policy that the implementation of PT tridharma activities was carried out online / online with the concept of work from home (WFH). The presence of work from home (WFH) raises pros and cons among academics. The test results between variables are as follows: 1) Work from home (WFH) has a direct and significant effect on motivation. Where the CR value of 13,914>1.96 and the p-value $(0,000)$ is smaller than 0.05; 2) Work from home (WFH) has a direct and significant effect on performance. Where the CR value of 2.557> 1.96 and the p-value (0.011) is smaller than 0.05; and Motivation does not have a direct and significant effect on performance. Where the CR value of $1.581<1.96$ and the p-value (0.114) is greater than 0.05. The results of this study provide an overview of the concept of work from home in the field of education, especially colleges can only carry out educational activities / teaching carried out online / online with applications that can be used together by lecturers and students such as Google classroom, e-learning and others Such research activities can also be carried out at home using the Google form in distributing questionnaires, but community service activities have not yet found a solution. Other work activities related to academic services are still carried out by work from home (WFH) and every activity is monitored regularly.
\end{abstract}

Keywords: Work from Home, Motivation, Performance. 


\section{Pendahuluan}

Pandemik Covid-19 yang melanda hampir seluruh negara di dunia tentu memberikan imbas negatif yang banyak dirasakan oleh kebanyakan orang. Total pasien yang terkonfirmasi Covid-19 hingga awal Mei 2020 mencapai angka 3.524.429 orang dari 187 negara di dunia. Menurut sumber yang sama di Indonesia sendiri sebaran data yang terkonfirmasi dari Gugus Tugas Percepatan Penanganan COVID Nasional mencapai angka 11.587 jiwa, sebagaimana tren grafik memperlihatkan dibawah ini :

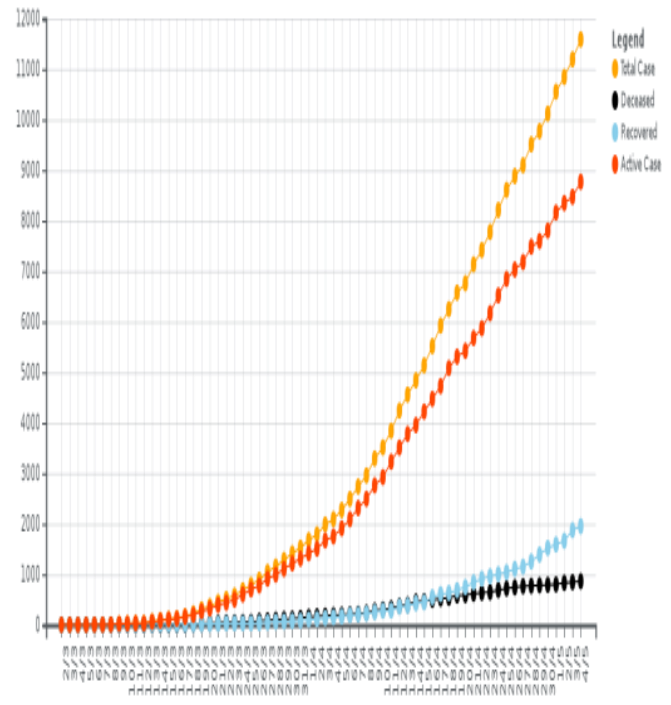

Sumber :Indonesian National Boardof Disaster Management, April 2020

Kehadiran Covid-19 dalam kehidupan ini menyebabkan banyak sekali aktivitas masyarakat atau organisasi perusahaan dan pemerintah seluruh dunia yang terkena berubah sehingga seluruh komponen tersebut harus melakukan adaptasi dengan kondisi yang darurat. Proses penyebaran Covid-19 di Indonesia juga bervariasi dengan relative cepat yang membuat masyarakat semakin resah sehingga setiap manusia mau tidak mau harus mengikuti kebijakan pemerintah dalam melakukan Pembatasan Skala Besar-Besaran (PSBB) demi memutus rantai penularan Covid-19.

Beberapa daerah di Ibukota besar seperti Jakarta, Bandung, Surabaya bahkan Medan yang memiliki konfirmasi angka Covid-19 tertinggi telah menerapkan istilah social distancing dalam aktivitas dan interaksinya. Kemunculan social distancing dalam aktivitas masyarakat akibat Covid-19 menyebabkan berbagai perusahaan ikut serta menerapkan social distancing baik terhadap sesama karyawan bahkan pelanggan agar mata rantai Covid19 dapat ditekan, namun cara ini dianggap tidak cukup efektif karena intensitas interaksi masyarakat masih cukup tinggi serta semakin bertambahnya pasien yang terkonfirmasi Covid-19.

Di saat yang sama Pemerintah juga menghimbau untuk pelaksanaan belajar dan bekerja dilaksanakan dari rumah atau populer dengan istilah work from home (WFH), selama pandemik virus corona. Tidak sampai disitu saja, Covid-19 juga memberikan dampak serius bagi semua aspek kegiatan seperti perekonomian, bisnis, investasi, travelling, sosial, dan budaya serta terutama pada dunia pendidikan. Hal inilah yang melatarbelakangi lima kebijakan pendidikan masa darurat Covid-19 antara lain : 1) Pembelajaran daring untuk anak sekolah, 2) Kuliah daring, 3) Ujian Nasional 2020 ditiadakan, 4) UTBK SBMPTN 2020 diundur dan 5) Pelaksanaan SNMPTN masih dalam pengkajian.

Upaya pencegahan meluasnya Covid-19, banyak institusi pemerintah, perusahaan BUMN, perusahaan swasta termasuk Perguruan Tinggi Negeri/Swasta ikut serta telah mengeluarkan kebijakan work from home (WFH). Dasar hukum mengenai work from home (WFH) atau bekerja di rumah selama wabah Covid-19 dapat dikaitkan dengan ketentuan Pasal 86 ayat (1) huruf a UndangUndang No.13 Tahun 2013 tentang Ketenagakerjaan, dimana setiap pekerja/buruh mempunyai hak untuk memperoleh perlindungan atas keselamatan dan kesehatan kerja.

Kesadaran yang tinggi ini merupakan bentuk penghargaan kepada karyawan bahwa keselamatan dan kesehatan kerja karyawan merupakan hal yang utama, karena dengan sumber daya manusia perusahaan dalam kondisi apapun harus tetap dikendalikan agar tidak menyimpang dari tujuan-tujuannya. Tanpa sumber daya manusia (karyawan) aktivitas organisasi akan lumpuh dan dapat mengganggu stabilitas pelayanan sehingga menyebabkan perusahaan merugi akibat masa darurat Covid-19. Disamping itu ada beberapa perusahaan lain yang enggan untuk menerapkan work from home (WFH) di masa darurat Covid-19 dengan alasan aktivitas perusahaan tidak dapat dilakukan di rumah (work from home). Universitas Labuhanbatu sebagai perguruan tinggi swasta merupakan jenis perusahaan jasa ikut serta melaksanakan kebijakan work form home (WFH) semenjak ditemukan kasus pasien Covid-19 pertama di Kabupaten Labuhanbatu sebagai upaya menekan penyebaran virus corona dalam lingkungan kampus Universitas Labuhanbatu. Dengan diterapkannya work from home (WFH) mengakibatkan seluruh aktivitas pelayanan akademik berubah-ubah mulai dari adanya pelarangan interaksi langsung antara mahasiswa dengan dosen kini beralih menjadi secara daring termasuk perkuliahan/ pembelajaran, pelaksanaan ujian, pelayanan bimbingan skripsi serta pelayanan akademik lainnya.

Kondisi masa darurat ini semakin membuat seluruh civitas akademika semakin bingung termasuk pimpinan masing-masing unit kerja di lingkungan Universitas Labuhanbatu dalam mencapai kinerja yang maksimal. Tingginya beban kerja yang harus diselesaikan oleh Dosen sebagai 
aktor utama keberhasilan proses pelaksanaan pembelajaran, melakukan penelitian dan pengabdian kepada masyarakat yang biasanya dilakukan secara manual dan online/ daring. Sejak diberlakukannya work from home (WFH) disambut baik semua civitas akademika sebagai upaya memutus mata rantai Covid-19 terutama dilingkungan Universitas Labuhanbatu. Melihat kenyataan demikian di masa darurat Covid-19, perlu dilakukan pengkajian secara empiris mengenai tingkat motivasi Dosen work from home (WFH) dalam mencapai kinerja di masa pandemik Covid-19, sekaligus memberikan solusisolusi yang memungkinkan kepada pimpinan Universitas Labuhanbatu dalam mengambil keputusan terkait bagaimana pengelolaan dan pelayanan akademik di masa darurat pandemik Covid-19.

\section{Kajian Teori}

Manusia diartikan sebagai pemanfaatan aset dari perusahaan untuk mencapai semua tujuan yang telah ditetapkan oleh organisasi tersebut. Dalam menghadapi situasi atau masa darurat Covid-19 setiap elemen penting yang terlibat dalam organisasi harus mampu beradaptasi dengan kondisi tersebut termasuk berkaitan dengan motivasi. Munculnya kebijakan work from home dalam upaya memutus mata rantai Covid-19 dilingkungan organisasi sebagai upaya pekerjaan kantor yang memungkinkan dapat diselesaikan sesuai intruksi pimpinan. Work from home (WFH) merupakan sebuah istilah di masa darurat Covid-19 yang berarti bekerja dari rumah. Lebih luasnya seseorang dapat melakukan pekerjaan dari rumah, cafe, atau di tempat yang nyaman sesuai dengan kebutuhan karyawan. Selain itu, guna mencapai tujuan-tujuan organisasi tersebut diperlukan motivasi daan dukungan berbagai pihak seperti pimpinan puncak, level manajemen dan lower manajemen. Hasil penelitian Rupietta dan Beckmann (2018) bahwa secara empiris kami menunjukkan bahwa bekerja dari rumah memiliki pengaruh positif yang signifikan terhadap upaya kerja. Selain itu, kami menemukan bahwa frekuensi bekerja dari rumah juga sangat penting. Semakin sering karyawan bekerja dari rumah, semakin tinggi pula upaya kerja yang mereka berikan. Varma (2017) motivasi merupakan stimulasi penting yang mengarahkan perilaku manusia. Tidak ada individu yang samasikap atau perilaku, maka di tengah keberagaman ini organisasi diharapkan membingkai praktik yang akan dapat memuaskan kelompok dan bukan hanya individu. Sabir (2017) motivasi secara umum disebut sebagai alasan bertindak atau berperilaku dengan cara tertentu. Motivasi juga bisa diartikan sebagai arah perilaku seseorang atau apa yang menyebabkan seseorang menginginkannya mengulangi suatu perilaku dan sebaliknya. Motif itulah yang mendorong orang untuk bertindak dengan cara tertentu, atau setidaknya mengembangkan kecenderungan untuk perilaku tertentu. Karyawan yang memiliki motivasi baik secara umum akan mempengaruhi pencapaian kinerjanya, kinerja merupakan segala hasil capaian dari segala bentuk tindakan dan kebijakan dalam rangkaian usaha kerja pada jangka waktu tertentu guna mencapai suatu tujuan. Perhatian kinerja ditengah masa pandemik Covid-19 adalah bagian penting dari organisasi karena bukan hanya mencapai hasil kerja tetapi harus memperhatikan proses dan aspek penting lainnya. Pradhan dan Jena (2017), kinerja adalah konsep multi komponen dan pada tingkat fundamental seseorang dapat membedakan prosesnya aspek kinerja, yaitu, keterlibatan perilaku dari hasil yang diharapkan. Oleh karena itu, setiap tenaga kerja dalam melaksanakan tugasnya dan tanggungjawab secara legal serta tidak melanggar hukum dan sesuai dengan moral maupun etika.

\section{Kerangka Konseptual}

Semenjak diberlakukannya work from home oleh Pemerintah di masa puncak pandemik Covid-19 kepada seluruh institusi dan perusahaanperusahaan termasuk perguruan tinggi, menyebabkan perguruan tinggi ikutserta mengikuti kebijakan Pemerintah sebagai langkah memutus mata rantai Covid-19. Hasilnya kebijakan ini menuai polemik bagi perusahaan-perusahaan yang belum terkena zona merah terutama bagi karyawan. Felstead dan Henseke (2017) menunjukkan bahwa detasemen pekerjaan dari tempat adalah tren yang berkembang, artikel mereka juga menunjukkan bahwa sementara kerja jarak jauh dikaitkan dengan komitmen organisasi yang lebih tinggi, kepuasan kerja dan terkait pekerjaan kesejahteraan.

Work from home tidak dapat dilakukan oleh setiap perusahaan, hanya beberapa perusahaan termasuk perguruan tinggi yang dapat menerapkan work from home. Walaupun dapat diterapkan bagi perguruan tinggi tetap saja implementasi work form home memiliki kelebihan dan kelemahan. Netteland (2009) hasil penelitiannya bahwa penerapan $e$ learning akan memberikan wawasan baru yang memiliki relevansi dilingkungan kerja.Sebagai perguruan tinggi swasta yang sedang berkembang, Universitas Labuhanbatu mendukung penuh anjuran Pemerintah menerapkan work from home tersebut. Implementasi work from home dalam kampus tentu berkaitan dengan motivasi dan kinerja semua karyawan yang berada didalamnya. Guna memudahkan alur pikir penelitian, penulis akan menggambarkan kerangka konseptual sebagai berikut : 


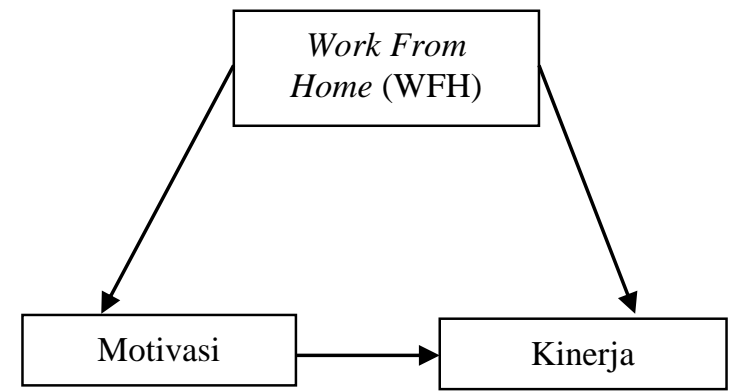

Sumber : Data Diolah, 2020

Gambar 1.

Kerangka Konseptual

\section{Hipotesis}

Berdasarkan pemaparan-pemaparan di atas, maka dari itu peneliti mengajukan hipotesis antara lain :

H1 : Work from home (WFH) berpengaruh terhadap motivasi.

$\mathrm{H} 2$ : Work from home (WFH) berpengaruh terhadap kinerja.

H3 : Motivasi berpengaruh terhadap kinerja.

\section{Metode Penelitian}

Pendekatan penelitian ini menggunakan metode penelitian kuantitatif. Yang artinya peneliti berupaya menerapkan pola pikir deduktif yang bersifat rasional, empiris dan top-down suatu fenomena dengan menggunakan konsep-konsep yang umum untuk menjelaskan fenomena yang bersifat khusus, sehingga teknik pengumpulan dan jenis data yang tepat digunakan dalam penelitian ini data primer berupa kuesioner (yang dilakukan secara online menggunakan google form) dan data sekunder melalui akses internet. Penelitian ini dilakukan pada kampus Universitas Labuhanbatu yang beralamat Jl. S. M. Raja No. 126A Aek Tapa-Rantauprapat, sedangkan populasi yang mendukung penelitian ini merupakan karyawan yang berstatus Dosen Tetap yang melakukan pekerjaan secara work from home, keseluruhan berjumlah 112 orang terdiri dari 41 Dosen Fakultas Ekonomi dan Bisnis (FEB), 13 Dosen Fakultas Hukum (FH), 36 Dosen Fakultas Keguruan dan Ilmu Pendidikan (FKIP) dan 22 Dosen Fakultas Sains dan Teknologi (FST). Maka, peneliti memutuskan mengambil 112 orang Dosen sekaligus menjadi sampel dalam penelitian ini. Teknik pengambilan sampling yang cocok dengan penelitian ini adalah teknik purposive sampling dengan kriteria/pertimbangannya adalah Dosen Universitas Labuhanbatu bekerja secara work from home. Sementara itu, untuk metode analisis data adalah analysis jalur (path analysis) adalah teknik statistik yang memberikan kemungkinan hubungan sebab akibat baik langsung maupun tidak langsung di antara satu set variabel. Analisis jalur dimulai dengan mengembangkan diagram dengan panah menghubungkan variabel dan menunjukkan aliran kasual atau arah sebab-akibat. Setiap jalur menunjukkan dua variabel yang dihubungkan oleh salah satu panah (garis, biasanya lurus, dengan panah di salah satunya ujung) atau kabel (garis, biasanya melengkung, tanpa mata panah), atau sling (dengan dua mata panah) (Nurmawati dan Kismiantini, 2019). Serta merupakan perluasan dari analisis regresi berganda atau penggunaan analisis regresi untuk menaksir hubungan kausalitas antar variabel (model causal) yang telah ditetapkan sebelumnya berdasarkan teori yang menggunakan aplikasi SPSS dan AMOS.

\section{Hasil dan Pembahasan}

Sebelum dilakukan pengujian hipotesis, terlebih dahulu peneliti harus melakukan beberapa pengujian sebagai guna memenuhi persyaratan dalam penelitian antara lain :

\section{Uji Validitas dan Reliabilitas}

Suatu hasil dinyatakan valid dan reliabel dengan syarat hasil validitas dan reliabilitas harus memiliki nilai yang lebih tinggi dari batas yang ditentukan. Pengujian validitas statistik mengacu pada kriteria :

- Apabila $r_{\text {hitung }}>r_{\text {tabel }}$ (0.3) maka dinyatakan valid.

- Apabila $r_{\text {hitung }}<r_{\text {tabel }}$ (0.3) maka dinyatakan tidak valid.

Untuk mempermudah perhitungan uji validitas dan reliabilitas instrumen dalam penelitian ini menggunakan aplikasi Microsoft Excel dan Statistical Program of Social Science) 20 version for windows. Berikut ini hasil pengujian validitas dan reliabilitas instrumen seluruh variabel penelitian antara lain :

TABEL 1.

HASIL PENGUJIAN VALIDITAS DAN RELIABILITAS

\begin{tabular}{|c|c|c|c|}
\hline No. & $\begin{array}{l}\text { Indikator } \\
\text { Variabel }\end{array}$ & $\begin{array}{c}\text { Corrected } \\
\text { Item-Total } \\
\text { Correlation }\end{array}$ & $\begin{array}{c}\text { Cronbach's } \\
\text { Alpha }\end{array}$ \\
\hline \multicolumn{4}{|c|}{ Variabel Work From Home $(\mathrm{X})$} \\
\hline 1 & WFH1 & 0.524 & \multirow{8}{*}{0.858} \\
\hline 2 & WFH2 & 0.324 & \\
\hline 3 & WFH3 & 0.629 & \\
\hline 4 & WFH4 & 0.749 & \\
\hline 5 & WFH5 & 0.698 & \\
\hline 6 & WFH6 & 0.684 & \\
\hline 7 & WFH7 & 0.683 & \\
\hline 8 & WFH8 & 0.766 & \\
\hline \multicolumn{4}{|c|}{ Variabel Motivasi (Y) } \\
\hline 9 & Motivasi1 & 0.715 & \multirow{7}{*}{0.888} \\
\hline 10 & Motivasi2 & 0.598 & \\
\hline 11 & Motivasi3 & 0.715 & \\
\hline 12 & Motivasi4 & 0.410 & \\
\hline 13 & Motivasi5 & 0.849 & \\
\hline 14 & Motivasi6 & 0.847 & \\
\hline 15 & Motivasi7 & 0.710 & \\
\hline \multicolumn{4}{|c|}{ Variabel Kinerja $(\mathbf{Z})$} \\
\hline 16 & Kinerja1 & 0.785 & \multirow{3}{*}{0.873} \\
\hline 17 & Kinerja2 & 0.778 & \\
\hline 18 & Kinerja3 & 0.725 & \\
\hline
\end{tabular}




\begin{tabular}{|l|l|l|l|}
\hline 19 & Kinerja4 & 0.509 & \\
\hline 20 & Kinerja5 & 0.725 \\
\hline 21 & Kinerja6 & 0.601 & \\
\hline
\end{tabular}

Dari data pada Tabel 1, diketahui bahwa hasil pengujian validitas seluruh indikator variabel work from home, motivasi dan kinerja memiliki nilai rhitung lebih besar dari (0.300) yang berarti valid. Sedangkan pada uji reliabilitas biasanya menggunakan batasan 0.6 yang berarti baik atau reliabel. Menurut Siagian and Khair (2018) bahwa nilai $r$ kritis yang ditetapkan adalah antara 0.6 dan 0.7. Dari data diatas bahwa seluruh variabel variabel work from home, motivasi dan kinerja memiliki nilai cronbach's alpha lebih besar dari nilai $r$ kritis yang ditetap. Dengan demikian dapat disimpulkan hasil uji validitas dan reliabilitas instrumen memenuhi syarat yang ditetapkan.

\section{Deskripsi Profil Responden}

Selanjutnya dari hasil penyebaran angket secara online (google form) kepada seluruh sampel berjumlah 112 orang yang mengisi dan memberikan respon sesuai kebutuhan penelitian hanya berjumlah 80 orang, sedangkan sisanya 32 orang tidak memberikan tanggapan. Berikut ini hasil penyebaran angket secara online yang telah dilakukan, diperoleh gambaran profil responden pada penelitian ini :

TABEL 2.

PROFIL RESPONDEN

\begin{tabular}{|l|l|l|}
\hline No. $\quad$ Kriteria & Frekuensi & Persentase \\
\hline 1) Jenis Kelamin & 43 & 53,8 \\
\hline Laki-laki & 37 & 46,3 \\
\hline Perempuan & \multicolumn{1}{|l|}{} \\
\hline 2) Usia & 37.5 \\
\hline 25-30 tahun & 30 & 43.8 \\
\hline 31-40 tahun & 35 & 18.8 \\
\hline 41-50 tahun & 15 & 95.0 \\
\hline 3) Pendidikan & 76 & 5.0 \\
\hline S2 & 4 & 17.5 \\
\hline S3 & 14 & 25.0 \\
\hline 4) Lama Bekerja & 57.5 \\
\hline 1-3 tahun & 20 & 37.5 \\
\hline 4-6 tahun & 46 & 12.5 \\
\hline diatas 6 tahun & 31.3 \\
\hline 5) Asal Fakultas & 18.8 \\
\hline FEB & 10 & \\
\hline FH & 25 & \\
\hline FKIP & 15 & \\
\hline FST \\
Sumber : Data Diolah, 2020
\end{tabular}

Dari data pada Tabel 2, diketahui bahwa gambaran profil responden berdasarkan jenis kelamin didominasi oleh laki-laki, berdasarkan usia didominasi oleh usia 31-40 tahun, berdasarkan pendidikan didominasi pendidikan S2 dan S3, berdasarkan lama bekerja didominasi oleh lama bekerja di atas 6 tahun dan berdasarkan asal fakultas didominasi oleh Fakultas Ekonomi dan Bisnis (FEB).

\section{Analisis Jalur}

Pada tahap ini akan dilakukan pengujian hipotesis dengan model analisis jalur menggunakan software AMOS. Untuk mengetahui hasil pengujian hubungan antar variabel dapat dilihat pada Gambar dibawah ini:

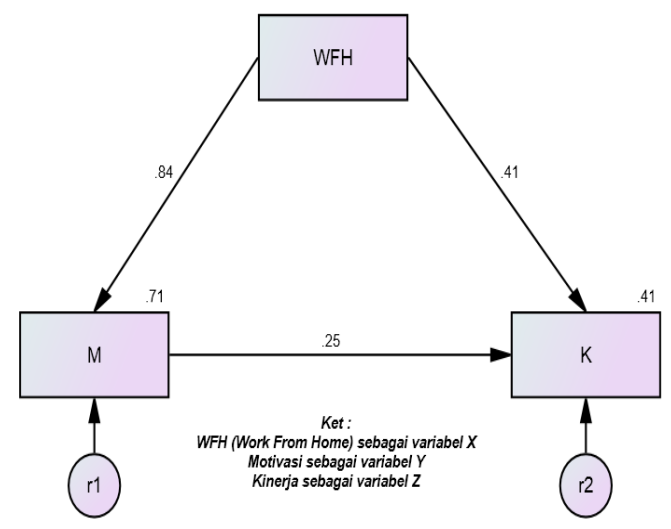

Sumber : Data Diolah, 2020

Gambar 2.

Model Analisis Jalur

Dari hasil pengujian hipotesis seluruh variabel menggunakan analisis jalur dapat diperoleh hasil yang menunjukkan sejauh mana hubungan antar variabel sebagai berikut :

TABEL 3.

REGRESSION WEIGHTS

\begin{tabular}{|lll|llll|}
\hline & & & Estimate & S.E. & C.R. & P \\
\hline $\mathrm{M}$ & $<---$ & WFH & .847 & .061 & 13.914 & $* * *$ \\
$\mathrm{~K}$ & $<---$ & WFH & .186 & .073 & 2.557 & .011 \\
$\mathrm{~K}$ & $<---$ & $\mathrm{M}$ & .114 & .072 & 1.581 & .114 \\
\hline
\end{tabular}

Berdasarkan pada Tabel 3 diatas, dapat diperoleh hasil pengujian antar variabel sebagai berikut :

1. Work from home (WFH) berpengaruh dan signifikan langsung terhadap motivasi. Dimana nilai CR sebesar 13,914>1,96 dan nilai p-value $(0,000)$ lebih kecil dari 0,05 .

2. Work from home (WFH) berpengaruh dan signifikan langsung terhadap kinerja. Dimana nilai CR sebesar 2,557 > 1,96 dan nilai $\mathrm{p}$-value $(0,011)$ lebih kecil dari 0,05 .

3. Motivasi tidak berpengaruh langsung dan tidak signifikan terhadap kinerja. Dimana nilai CR sebesar $1,581<1,96$ dan nilai p-value $(0,114)$ lebih besar dari 0,05 . 


\section{Pembahasan}

Berdasarkan hasil pengujian hipotesis analisis jalur, maka dijelaskan sebagai berikut :

1. Pada hipotesis pertama diketahui bahwa work from home (WFH) memiliki pengaruh langsung dan signifikan terhadap motivasi. Hal ini berarti bahwa seluruh Dosen yang memahami situasi yang berkaitan dengan Covid-19 dan sebagai upaya memutus mata rantai Covid-19 di perguruan tinggi maka pihak internal perguruan tinggi melaksanakan anjuran pemerintah untuk memberlakukan work form home (WFH), termasuk aktivitas pendidikan, pengajaran, pembelajaran, pelayanan akademik dan penelitian serta pengabdian kepada masyarakat. Hal ini sesuai dengan hasil penelitian (Liang et al. 2015) bahwa work from home yang dilakukan selama sembilan bulan kepada karyawan Call Center mengalami peningkatan kinerja $13 \%$ yang membuatkan karyawan merasakan kepuasan kerja. Rupietta dan Beckmann (2016) hasil penelitian baha : "Our empirical results show that working from home has a significantly positive influence on work effort. Moreover, we find that also the frequency of working from home is crucial. The more often employees work from home, the higher is the work effort they provide". Artinya hasil empiris kami menunjukkan bahwa bekerja dari rumah memiliki pengaruh positif yang signifikan terhadap upaya kerja. Selainitu, kami juga menemukan bahwa frekuensi bekerja dari rumah sangatlah penting. Semakin sering karyawan bekerja dari rumah, semakin tinggi upaya kerja yang mereka berikan.

2. Pada hipotesis kedua diketahui bahwa work from home (WFH) memiliki pengaruh langsung dan signifikan terhadap kinerja. Setelah pimpinan perguruan tinggi mengikuti anjuran pemerintah untuk melaksanakan work from home (WFH), beberapa hal positif yang diperoleh dari work from homes esuai dengan penelitian (Purwanto et al. (2020) antara lain pekerjaan menjadi lebih fleksibel, mengurangi biaya transportasi, produktivitas kerja meningkat, memperoleh kepuasan kerja, keseimbangan hidup dengan pekerjaan, dan terhindari dari distraksi. Sejalan dengan penelitian lainnya (Nordin, Mohd Baidzowi, and Razak 2016) bahwa menurut karyawan di Malaysia memiliki sudut pandang bekerja dari rumah menjadi tantangan sebuah konsep kerja yang potensial fleksibel.

3. Pada hipotesis ketiga diketahui bahwa motivasi tidak memiliki pengaruh langsung dan tidak signifikan terhadap kinerja. Dapat dijelaskan bahwa dari hasil penelitian ini beberapa responden memberikan respon menyimpulkan work form home (WFH) yakni : menyebabkan biaya internet dan komunikasi dengan mahasiswa semakin ribet karena harus bergantung pada paket data, komunikasi menjadi kurang lancar baik dengan rekan kerja dan mahasiswa, stress yang tidak teratur karena ada tuntutan yang harus dilakukan karena situasi Covid-19, dan hanya beberapa jenis kegiatan pekerjaan yang dapat dilakukan menggunakan konsep ini seperti pengajaran, ujian, proses bimbingan, dan pekerjaan yang mendukung aplikasi. Hal ini sesuai dengan Saludin, Karia, and Hassan (2013) bahwa dalam artikelnya pelaksanaan work from home (WFH) di Malaysia masih langka dalam implementasinya.

\section{Kesimpulan}

Dari hasil penelitian ini diketahui bahwa work from home (WFH) telah menimbulkan pro dan kontra dalam implementasinya, namun work from home (WFH) dalam dunia pendidikan melalui hasil penelitian ini lebih memberikan gambaran konsep work from home bidang pendidikan khususnya perguruan tinggi hanya dapat melakukan kegiatankegiatan pendidikan/pengajaran dilakukan daring/online dengan aplikasi-aplikasi yang dapat digunakan secara bersama oleh Dosen dan mahasiswa misalnya google classroom, e-learning dan lainnya, kegiatan penelitian demikian juga dapat dilakukan dirumah dengan menggunakan google form dalam penyebaran angket, namun untuk kegiatan pengabdian kepada masyarakat belum memperoleh solusi. Kegiatan pekerjaan lainnya terkait dengan pelayanan akademik tetap dilakukan secara work from home (WFH) dan setiap aktivitas dipantau secara berkala.

\section{Daftar Pustaka}

A. Felstead, Alan, and Golo Henseke. 2017. "Assessing the Growth of Remote Working and Its Consequences for Effort, Well-Being and Work-Life Balance." New Technology, Work and Employment 32 (3): 195-212. https://doi.org/10.1111/ntwe.12097.

B. Liang, James, John Roberts, Zhichun Jenny Ying, Jennifer Cao, Mimi Qi, and Maria Sun. 2015. "Does Working From Home Work? Evidence From A Chinese Experiment * Nicholas Bloom I . Introduction Working from Home ( WFH ; Also Called Telecommuting or Tel- Ework ) Is Becoming an Increasingly Common Practice. In the United States, the Proportion of E." The Quarterly Journal of Economics $130 \quad$ (1): 165-218. https://doi.org/10.1093/qje/qju032.Advance.

C. Netteland, Grete. 2009. "Implementation of ELearning in a Large Organization: The Critical Role of Relevance to Work." International Journal of Advanced Corporate Learning 
$\begin{array}{llll}(I J A C) & 2 & \text { (3): } & 58-65 .\end{array}$

https://doi.org/10.3991/ijac.v2i3.1002.

D. Nordin, Nurul Nadia, Fateha Maizatul Mohd Baidzowi, and Ruzanna Ab Razak. 2016. "Understanding the Work At Home Concept, Its Benefits and Challenges Towards Employees." Social Sciences Research 2016 (July): 109-18.

E. Nurmawati, W. P., and Kismiantini. 2019. "Path Analysis for Determining Health Factors in Indonesia." Journal of Physics: Conference Series 1320 (1). https://doi.org/10.1088/17426596/1320/1/012018.

F. Pradhan, Rabindra Kumar, and Lalatendu Kesari Jena. 2017. "Employee Performance at Workplace: Conceptual Model and Empirical Validation." Business Perspectives and Research 5 (1): 69-85. https://doi.org/10.1177/2278533716671630.

G. Purwanto, Agus, Masduki Asbari, Mochammad Fahlevi, Abdul Mufid, Eva Agistiawati, Yoyok Cahyono, and Popong Suryani. 2020. "Impact of Work From Home (WFH) on Indonesian Teachers Performance During the Covid-19 Pandemic: An Exploratory Study." International Journal of Advanced Science and Technology 29 (5): 6235-44.

H. Rupietta, Kira, and Michael Beckmann. 2018. "Working from Home: What Is the Effect on Employees' Effort?" Working from Home: What Is the Effect on Employees' Effort? 70 (1): 25-55. https://doi.org/10.1007/s41464017-0043-x.

I. Sabir, Almas. 2017. "Motivation: Outstanding Way to Promote Productivity in Employees." American Journal of Management Science and Engineering $\quad 2 \quad$ (3): 35. https://doi.org/10.11648/j.ajmse.20170203.11.

J. Saludin, Nurul, Noorliza Karia, and Hasnanywati Hassan. 2013. "Green Economy: Researching Working from Home in Building Sector." The Journal of Southeast Asian Research, no. November: 1-9. https://doi.org/10.5171/2013.273189.

K. Siagian, Tomy Sun, and Hazmanan Khair. 2018. "Pengaruh Gaya Kepemimpinan Dan Lingkungan Kerja Terhadap Kinerja Karyawan Dengan Kepuasan Kerja Sebagai Variabel Intervening." Maneggio: Jurnal Ilmiah Magister Manajemen 1 (1): 59-70. https://doi.org/10.30596/maneggio.v1i1.2241.

L. Varma, Chandrakant. 2017. "Importance of Employee Motivation \& Job Satisfaction for Organizational Performance." International Journal of Social Science \& Interdisciplinary Research 6 (2): 10-20.
M. https://manado.tribunnews.com/2020/03/28/lak ukan-7-hal-ini-sebagai-antisipasi-virus-coronaketika-anda-harus-bekerja-di-luar-rumah diakses pada tanggal 29 Maret 2020 pukul 15.00 WIB.

N. https://www.worldometers.info/coronavirus/\#c ountriesdiakses pada tanggal 5 Mei 2020 pukul 20.00 WIB.

O. https://www.ctc-n.org/aboutctcn/organisations/indonesian-national-boarddisaster-management diakses pada tanggal 7 Mei 2020 pukul 11.00 WIB.

P. https://www.djkn.kemenkeu.go.id/artikel/baca/ 13014/Bekerja-dari-Rumah-Work-FromHome-Dari-Sudut-Pandang-Unit-KepatuhanInternal.html diakses pada tanggal 9 Mei 2020 pukul 12.00 WIB.

Q. https://sevima.com/5-kebijakan-pendidikanmasa-darurat-corona/ diakses pada tanggal 10 Mei 2020 pada pukul 14.00 WIB.

R. https://www.hukumonline.com/klinik/detail/ula $\underline{\text { san/lt5e7326fd25227/ketentuan-pelaksanaan-i- }}$ work-from-home-i-di-tengah-wabah-corona/ diakses pada tanggal 15 Mei 2020 pada pukul $08.00 \mathrm{WIB}$.

S. https://www.statistikian.com/2012/10/penelitia n-kuantitatif.html diakses pada tanggal $16 \mathrm{Mei}$ 2020 pada pukul 19.00 WIB.

T. https://www.bizjournals.com/bizjournals/howto/human-resources/2017/10/how-to-makework-from-home-truly-work.html diakses pada tanggal 17 Mei 2020 pada pukul 20.00 WIB.

U. https://www.eejournal.com/article/work-fromhome-survival-guide/ diakses pada tanggal 17 Mei 2020 pukul 22.00 WIB.

V. https://hbr.org/2015/01/a-working-from-homeexperiment-shows-high-performers-like-itbetter diakses pada tanggal 19 Mei 2020 pada pukul 10.00 WIB.

\section{Internet :}

